\title{
EDUCAÇÃO E EMPODERAMENTO FEMININO DE ALUNAS EM QUEIMADAS-PB, BRASIL
}

\section{EDUCATION AND FEMALE EMPOWERMENT OF STUDENTS IN QUEIMADAS-PB, BRAZIL}

\section{EDUCACIÓN Y EMPODERAMIENTO FEMENINO DE ESTUDIANTES EN QUEIMADAS-PB, BRASIL}

\author{
Maria Leidiane Araújo SILVA ${ }^{1}$
}

Ana Caroline Pereira da SILVA ${ }^{2}$

1. Pedagoga. Mestre em Ciências da Educação. E-mail: leydianearaujo2013@gmail.com.

2. Graduada em Letras/Espanhol. Professora do Instituto Federal de Educação da Paraíba. Programa de Pós-Graduação em Linguagem e Ensino Universidade Federal de Campina Grande-PB. E-mail: karolspanhol@gmail.com.

\begin{abstract}
RESUMO: Esse estudo teve como objetivo analisar o processo de escolarização e o empoderamento das mulheres alunas da Educação de Jovens e Adultos na cidade de Queimadas-PB. Tratou-se de uma pesquisa qualitativa, com uso de questionário contendo questões abertas e fechadas, aplicadas a 12 alunas que cursam a Educação de Jovens e Adultos na cidade de Queimadas-PB em de 2019. Constatou-se que o processo de escolarização age como fator atuante e por vezes libertador na vida dessas mulheres, uma vez que o acesso à educação escolar oportunizou várias modificações em suas vidas, resultando assim na conquista da autonomia, no acesso a oportunidades, em sua formação crítica, uma vez que o conhecimento além de emancipar ele empodera, influencia na elevação da autoestima e num melhor desempenho em suas atividades. O motivo que lhes fizeram regressar aos estudos está direcionado ao ato fazer bom uso da prática de leitura e escrita, a fim de modificar várias ações em suas vidas, assim como almejar elevar o nível de conhecimento com intuito de se valorizarem pessoalmente, conhecendo seus direitos e lutando para que tais sejam cumpridos e consequentemente alterarem sua qualidade de vida, na qual buscam elevar o nível de escolarização, valorização profissional, respeito, autonomia e liberdade.
\end{abstract}

Palavras-chave: Escolarização de mulheres. Empoderamento. Educação de Jovens e Adultos.

\begin{abstract}
This study aimed to analyze the schooling process and the empowerment of female students of Youth and Adult Education in the city of Queimadas-PB. It was a qualitative research, with the use of a questionnaire containing open and closed questions, applied to 12 students who are studying Youth and Adult Education in the city of Queimadas-PB in 2019. It was found that the schooling process acts as an active and sometimes liberating factor in the lives of these women, since access to school education has made several changes in their lives possible, thus resulting in the achievement of autonomy, access to opportunities, in their critical training, since knowledge in addition to emancipating it empowers, influences the increase of self-esteem and a better performance in its activities. The reason they made them return to their studies is directed to the act to make good use of the practice of reading and writing, in order to modify various actions in their lives, as well as aiming to raise the level of knowledge in order to value themselves personally, knowing their rights and fighting for these to be fulfilled and consequently altering their quality of life, in which they seek to raise the level of education, professional appreciation, respect, autonomy and freedom.
\end{abstract}

Keywords: Schooling of women. Empowerment. Youth and Adult Education.
RESUMEN: Este estudio tuvo como objetivo analizar el proceso de escolarización y el empoderamiento de las alumnas de Educación de Jóvenes y Adultos en la ciudad de Queimadas-PB. Se trató de una investigación cualitativa, con el uso de un cuestionario de preguntas abiertas y cerradas, aplicado a 12 estudiantes que cursan estudios de Educación de Jóvenes y Adultos en la ciudad de Queimadas-PB en 2019. Se encontró que el proceso de escolarización actúa como factor activo y en ocasiones liberador en la vida de estas mujeres, ya que el acceso a la educación escolar ha posibilitado varios cambios en su vida, resultando así en el logro de la autonomía, el acceso a oportunidades, en su formación crítica, ya que el conocimiento además de emanciparlo empodera, influye en el aumento de la autoestima y un mejor desempeño en sus actividades. La razón por la que los hicieron volver a sus estudios se dirige al acto de hacer un buen uso de la práctica de la lectura y la escritura, con el fin de modificar diversas acciones en sus vidas, así como también apuntar a elevar el nivel de conocimientos para poder valorarse personalmente, conociendo sus derechos. y luchando por que estos se cumplan y consecuentemente alteren su calidad de vida, en lo que buscan elevar el nivel de educación, valoración profesional, respeto, autonomía y libertad.

Palabras-clave: Escolarización de la mujer. Empoderamiento. Educación de jóvenes y adultos. 


\section{INTRODUÇÃO}

Ao abordar escolarização e as questões de gênero como elemento de análise, Scott (1995) nos oferece elementos importantes para a análise aqui pretendida. Seu estudo foi considerado um marco histórico que fundamenta epistemologicamente o conceito de gênero, definindo-o como um elemento constitutivo de relações sociais baseadas nas diferenças percebidas entre os sexos e como uma forma primária de dar significado às relações de poder. Isso significa dizer que o gênero está ligado às noções socialmente construídas de masculinidade e feminilidade, baseados nas relações de poder, já que estas não são neutras.

Historicamente, a mulher teve o acesso restrito à escolarização devido a uma sociedade marcada pelo modelo patriarcal que a conduziu à invisibilidade e ao espaço privado. Principalmente porque as mulheres começam o processo de escolarização tardiamente em relação aos homens, além de receber uma educação de má qualidade e frequentar quase que unicamente o ensino elementar (ROCHA-COUTINHO, 1994).

Infelizmente, de acordo com Castells (1999), essa questão é caracterizada por uma autoridade imposta institucionalmente, do homem sobre mulheres e filhos, no ambiente familiar, permeando toda organização da sociedade, da produção e do consumo, da política, à legislação e à cultura. Assim, o patriarcado funda a estrutura da sociedade e recebe reforço institucional; nesse contexto, relacionamentos interpessoais e personalidade são marcados pela dominação e violência.

As relações de gênero na sociedade patriarcal fazem parte da dinâmica social das desigualdades, nas quais podem ser pautadas as chamadas diferenças 'naturais' construídas socialmente entre os sexos masculino e feminino. Nesse sentido, as diferenças 'naturais', denominadas pelo seu sentido biológico, são instrumentos utilizados pela sociedade com seus respectivos critérios hierárquicos para a distribuição de papéis. A hierarquia é assim colocada como uma forma organizadora dos modelos classificatórios, como um modo de organizar o mundo, baseado no princípio do valor que confere significado às diferenças de valores de gêneros distintos.

Assim, é necessário e importante reconhecer a dimensão individual/percepções individuais do empoderamento feminino. Não se pode ignorar a alteração das distribuições do poder nas relações sociais entre os gêneros. Isto porque o empoderamento é um processo pessoal e político, cujas dimensões pessoais/internas e corporais não podem desvincular-se de suas conotações políticas, de impugnação das relações de poder vividas não somente nas relações familiares, nas quais as pessoas vivem cotidianamente e por sua vez, é parte da ordem social. Neste sentido, o empoderamento feminino deve ser priorizado como transformação de estruturas de subordinação, ou seja, como um processo de emancipação das mulheres e da sociedade atual. Desta forma, o objetivo geral do estudo foi analisar o empoderamento das mulheres alunas da EJA na cidade de Queimadas-PB, através de suas lutas, conquistas e avanços.

\section{METODOLOGIA}

Há muitas maneiras de se estudar e compreender as relações humanas seja pelo estudo dos fenômenos e das estruturas que caracterizam as organizações sociais, culturais, econômicas e políticas, seja pela reflexão crítica do 
homem e dos eventos que acontecem em seu cotidiano, ou ainda, pela linguagem e pela forma como as pessoas interagem entre si e atribuem mutualmente significados a partir dessas interações.

A pesquisa qualitativa é a única via, a meu ver, que a ontologia deste trabalho me permitiria seguir, dado seu cunho social e sua preocupação com a delimitação e superação de um problema. Isto posto, cabe delimitar o que vem a ser a pesquisa qualitativa e como ela conecta-se com as preocupações sociais cerne da matriz teórica desta pesquisa. Trata-se da escolha correta de métodos e teorias oportunos, no reconhecimento e na análise de diferentes perspectivas, nas reflexões dos pesquisadores a respeito de sua pesquisa como parte do processo de produção de conhecimento (FLICK, 2002, p. 20). Denzin e Lincoln (2006) apresentam uma perspectiva mais abrangente, segundo a qual:

\begin{abstract}
A palavra qualitativa implica uma ênfase sobre as qualidades das entidades e sobre os processos e os significados que não são examinados ou medidos experimentalmente (se é que são medidos de alguma forma), em termos de quantidade, volume, intensidade ou frequência. Os pesquisadores qualitativos ressaltam a natureza socialmente construída da realidade, a íntima relação entre o pesquisador e o que é estudado, e as limitações situacionais que influenciam a investigação. Esses pesquisadores enfatizam a natureza repleta de valores da investigação. Buscam soluções para as questões que realçam o modo como à experiência social é criada e adquire significado. Já os estudos quantitativos enfatizam o ato de medir e analisar as relações causais entre variáveis, e não processo. (DENZIN; LINCOLN, 2006 p. 23).
\end{abstract}

A pesquisa qualitativa é uma metodologia multidisciplinar. Em torno do termo pesquisa qualitativa, encontra-se uma família interligada e complexa de termos, conceitos e suposições (DENZIN; LINCOLN, 2006, p. 16). Existe atualmente, uma enorme variedade de métodos específicos disponíveis, cada um dos quais partindo de diferentes premissas em busca de objetivos distintos (FLICK, 2002, p. 17), tais como o estudo de caso, estudo de múltiplos casos, textos observacionais, históricos, diários, análise de conteúdo, análise do discurso, etnografia, etnografia, entrevista de grupo focal, dentre outros (DENZIN; LINCOLN, 2006; FLICK et al., 2004).

As análises qualitativas podem ser caracterizadas por serem essencialmente descritivas, englobando diversas técnicas e incluindo elementos subjetivos. Para Martins e Bicudo (1989) o recurso básico e inicial da pesquisa qualitativa é a descrição, fundamentada pelos modos de ser e conviver das pessoas envolvidas na pesquisa. A pesquisa qualitativa pode descrever detalhadamente os procedimentos de campo, dando a ela um grau de objetivação do fenômeno estudado, sendo que essas descrições acabam por se tornar ricas, levando a pesquisa a oferecer um maior grau de reflexividade ao pesquisador e à pesquisadora.

Segundo Vieira e Zouain (2004), a pesquisa qualitativa deve possuir uma pergunta que conduza a pesquisadora ou o pesquisador ao problema. Durante a fundamentação teórica o problema de pesquisa deve ser sustentado além de se apresentar sugestões para a superação deste problema. A partir da metodologia, estruturamse as perguntas da pesquisa e é delineado o desenho da pesquisa juntamente com as especificidades do método.

Para isso, os dados quantitativos foram obtidos através da aplicação de questionários nos meses de junho e julho de 2019.

O estudo do ponto de vista de sua natureza, pode ser caracterizado como uma Pesquisa Aplicada, pois objetiva gerar conhecimentos para aplicação prática dirigida à solução de problemas específicos. Envolve verdades e interesses locais. 
Do ponto de vista da forma de abordagem do problema pode ser quali-quantitativa. É uma Pesquisa Quantitativa porque analisa os dados baseada no uso da estatística e é uma pesquisa qualitativa, pois as pesquisadoras analisaram seus dados indutivamente.

De acordo com Gil (1999), do ponto de vista de seus objetivos, tratou-se de uma Pesquisa Descritiva, pois visou descrever as características de determinada população ou fenômeno ou o estabelecimento de relações entre variáveis. Envolvem o uso de técnicas padronizadas de coleta de dados: questionário e observação sistemática. Assume, em geral, a forma de levantamento.

A investigação utilizou como participantes, as alunas da escola, objeto da pesquisa, na cidade de Queimadas-PB que totalizaram 12 pesquisadas. Todas matriculadas e frequentando as aulas nas turmas da EJA referente às séries iniciais do Ensino Fundamental. Vale ressaltar que todas as alunas citadas nesta dissertação tiveram suas identidades preservadas devido aos princípios éticos da investigação.

A critério da pesquisadora foi atribuído os códigos M1, M2, .., M11 e M12, para as participantes da Pesquisa, dessa forma garantindo o direito ao anonimato, e assim poderem ser identificadas todas as falas das pesquisadas nos resultados.

Conforme Minayo (2014), a pesquisa qualitativa responde a questões muito particulares e se preocupa com um nível da realidade que não pode ser quantificado, como temas que adotam a perspectiva compreensiva ou interpretativa.

De acordo com Sampiere et al. (2006), para o enfoque qualitativo, a amostra é uma unidade de análise ou um grupo de pessoas, contextos, eventos, fatos, comunidades, dentre outros. Sobre o qual deve ser coletado dado sem que necessariamente seja representativo do universo da população estudada. O autor salienta que "(...) muitas vezes a amostra é o próprio universo de análise (...)" (SAMPIERE et al., 2006, p. 251).

Para coletar as informações necessárias sobre o conhecimento e aspirações dos pesquisados a respeito das tecnologias da informação e comunicação durante o processo investigativo optou-se em utilizar um questionário. Esse instrumento foi adaptado pela pesquisadora conforme Bezerra (2010), sendo constituído por 19 questões abertas e fechadas. Portanto, destaca-se que o questionário é uma das técnicas disponíveis mais importantes para a obtenção e registro dos dados. Sua versatilidade permite utilizá-lo como instrumento de investigação e de avaliação de pessoas, processos e programas de formação. É uma técnica de avaliação que pode incorporar aspectos quantitativos e qualitativos (GARCIA, 2003).

Segundo Fachin (2006), o questionário pode ser composto de questões que possibilitem respostas pessoais, mas também pode ser constituído de questões organizadas de forma que se possam levantar os dados para uma pesquisa, de qualquer forma pode ser feito com ou sem a assistência do pesquisador.

Nesse caso, principalmente, quando o(a) pesquisador(a) tiver o interesse em pesquisar uma situação singular e particular. Dessa forma, "o caso é sempre bem delimitado, devendo ter seus contornos claramente definidos no desenvolver do estudo" (LÜDKE; ANDRÉ, 1986, p. 17).

Nesse caso, o estudo que se preocupa com a constante reformulação dos seus pressupostos, uma vez que o conhecimento nunca está pronto. Com isso, a compreensão de determinado objeto será auxiliada, levando-se em 
conta o contexto em que acontece. Os fatores externos também podem ajudar na apreensão e interpretação da problemática estudada. A preocupação se dá em retratar a complexidade de uma situação particular, focalizando o problema em seu aspecto total.

Para a realização do presente estudo, foram utilizados vários conjuntos de procedimentos para ter sucesso nos objetivos propostos. A abordagem do estudo foi de natureza qualitativa, segundo a qual, para Triviños (1987, p. 175), não existe preocupação com números, medidas ou expressões quantitativas, expressando uma visão mais subjetiva dos atores envolvidos.

O universo da pesquisa foi composto por doze alunas da EJA, em uma escola da cidade de Queimadas-PB. A definição da quantidade de pesquisados que integram a amostra se baseou na literatura sobre pesquisa qualitativa (FLICK, 2002).

\section{RESULTADOS E DISCUSSÃO}

Quanto ao perfil social das pesquisadas, pode-se constatar que apesar de existir uma vasta diversidade na faixa etária entre as alunas, o que predomina na turma são as mulheres com idade acima dos 40 anos, sendo em sua grande maioria mulheres casadas $(41,67 \%)$, viúvas $(33,33 \%)$ e solteiras $(8,33 \%)$.

Em relação ao vínculo empregatício renumerado, constatou-se que a função de diarista $(33,33 \%)$ é a que mais se sobressai diante as demais funções, no entanto, vale mencionar que a função de provedoras do lar apresentou $41,67 \%$ das respostas.

Das alunas envolvidas na pesquisa, 66,67\% tem filhos, variando de um a seis filhos, restando o total de $33,33 \%$ que não tiveram filhos, destas, $8,33 \%$ vivem em situação de baixa renda, $75 \%$ sobrevivem com a importância de um salário mínimo para todas as despesas diárias, e apenas 16,67\% recebem acima de um salário mínimo, sendo que a maioria são provedoras do lar (Quadro 1).

Quadro 1. Perfil socioeconômico das pesquisadas quanto à idade, estado civil, profissão, $\mathrm{n}^{\mathrm{o}}$ de filhos, com quem residem e renda familiar. Queimadas-PB. 2019

\begin{tabular}{|c|c|c|c|c|c|c|c|}
\hline Pesquisadas & Idade & $\begin{array}{c}\text { Estado } \\
\text { Civil }\end{array}$ & Profissão & $\begin{array}{l}\mathrm{N}^{\circ} \text { de } \\
\text { Filhos }\end{array}$ & $\begin{array}{l}N^{0} \text { de Pessoas na } \\
\text { mesma residência }\end{array}$ & $\begin{array}{c}\text { Quem são } \\
\text { essas pessoas }\end{array}$ & Renda Familiar \\
\hline M1 & 45 & casada & Diarista & - & 2 & Ela e o marido & $\begin{array}{l}\text { Menos de um } \\
\text { salário mínimo }\end{array}$ \\
\hline M2 & 77 & viúva & Do lar & 03 & 2 & Ela e filho & Um salário mínimo \\
\hline M3 & 68 & viúva & Do lar & 05 & 4 & Filho e netos & Um salário mínimo \\
\hline M4 & 81 & Viúva & agricultora & 01 & 2 & Ela e marido & Um salário mínimo \\
\hline M5 & 50 & casada & Diarista & 04 & 4 & $\begin{array}{l}\text { Marido e } \\
\text { filhos }\end{array}$ & Um salário mínimo \\
\hline M6 & 70 & casada & $\begin{array}{c}\text { Ombreira da } \\
\text { igreja }\end{array}$ & - & 2 & Ela e marido & Dois salários \\
\hline M7 & 50 & solteira & Diarista & 03 & 2 & Ela e filho & Um salário mínimo \\
\hline M8 & 60 & casada & Do lar & 04 & 2 & Ela e filho & Dois salários \\
\hline M9 & 44 & separada & Diarista & 08 & 6 & $\begin{array}{l}\begin{array}{l}\text { Ela, mãe e } \\
\text { filhos }\end{array} \\
\end{array}$ & Um salário mínimo \\
\hline M10 & 50 & casada & Do lar & 03 & 4 & $\begin{array}{l}\text { Marido e } \\
\text { filhos }\end{array}$ & Um salário mínimo \\
\hline M11 & 55 & viúva & Do lar & 00 & 2 & Ela e sobrinho & Um salário mínimo \\
\hline M12 & 19 & solteira & Estudante & 00 & 3 & Ela, pai e mãe & Um salário mínimo \\
\hline
\end{tabular}


Nesse levantamento é notável que o vínculo empregatício dominante ainda seja aquele determinado pela classe conservadora e por vezes machista, na qual as mulheres deveriam ocupar cargos que já estão predeterminados para a classe feminina, fazendo-nos perceber que grande maioria destas advém de um modelo de ensino patriarcal baseados nas diferenças entre os sexos, pois as meninas eram educadas para cumprir seu papel de futura mãe e esposa dedicada aos trabalhos domésticos (PERROT, 2007, p.93).

Os dados nos revelaram que a idade predominante das mulheres no âmbito de estudo se enquadra em uma faixa etária acima dos 40 anos, em sua grande maioria, mulheres casadas, com quantidade variando de dois a seis filhos, sabendo-se que elas, em sua grande maioria, são provedoras do lar, no entanto, as que não enquadram nesse aspecto trabalham exercendo a função de diarista, cabendo também mencionar 75\% destas vivem em situação de baixa renda e sobrevivem com a importância de um salário mínimo.

Tais apontamentos corroboram os estudos realizados por Louro (1997), no qual se argumenta que as mulheres deveriam ser mais educadas do que instruídas, sendo assim as habilidades deveriam ser baseadas com intuito de ensino para realizar os afazeres do lar e educar seus futuros filho.

Em relação há quanto tempo deixaram de estudar quando criança, e até qual série estudaram? Obtivemos os seguintes resultados: $25 \%$ fizeram a $1^{\mathrm{a}}$ série do Ensino Fundamental, 25\% estudaram até a $2^{\mathrm{a}}$ série, 33,33\% a $3^{\mathrm{a}}$ série e apenas $8,33 \%$ a $4^{\mathrm{a}}$ série (Quadro 2), cabendo aqui mencionar que todos foram em nível incompleto. Analisando tais informações é possível afirmar que 50\% das envolvidas na pesquisa não tiverem oportunidade de no mínimo se alfabetizar visto que estas não chegaram a concluir nem a $2^{\mathrm{a}}$ série do Ensino Fundamental e quem apenas duas ingressaram na $4^{\mathrm{a}}$ série, porém não concluíram o ano letivo, "vale mencionar aqui que a nomenclatura utilizada na pesquisa é série e não ano devido ao sistema de ensino voltado para as turmas de EJA que ainda faz uso desse termo".

Em relação a qual idade estas conseguiram ir à busca do processo de escolarização, os resultados apontam que a idade varia entre 10 e 16 anos, ressaltando que a respondente M1 nunca estudou enquanto criança fazendonos perceber que o processo de escolarização para as mulheres ocorria de forma lenta e tardia.

Nesse aspecto os dados de nossa pesquisa coincidem com os estudos de Coutinho (1994), no qual afirma que além de a mulher ter tido um processo de escolarização tardia em relação aos homens, recebeu uma educação de má qualidade e que só poderia frequentar quase que unicamente o ensino elementar.

A perguntar sobre quais os motivos que lhes afastaram do processo de escolarização percebemos que a maioria (66,67\%) tiverem que abandonar os estudos para irem trabalhar (de forma renumerada ou não), nota-se dessa forma que essas escolhas não ocorreram de forma livre e espontânea, ao contrário, estas foram "forçadas" a abandonar os estudos com intuito de sobreviver em meio a uma sociedade injusta, onde as mulheres dispõem menos que os homens e eram impostas a trabalhar em sua grande maioria em funções domesticas e para cuidar dos filhos ou dos irmãos de menor idade que estas.

Seguindo o mesmo rumo da pergunta, $16,67 \%$ das participantes informaram que abandonaram os estudos por que não sentiam interesse em estudar, mostrando-nos mais uma vez que a falta de vontade e a ausência do apoio familiar, demonstram que a luta na época em que eram adolescentes era pela sobrevivência em meio a tantas 
dificuldades financeiras, a prioridade era trabalhar para ter o que comer, deixando assim os estudos em segundo plano (Quadro 2).

Quadro 2. Respostas das mulheres pesquisadas quanto aos motivos que as fizeram parar de estudar. Queimadas-PB. 2019

\begin{tabular}{|c|c|}
\hline Pesquisadas & Falas \\
\hline M1 & "nunca fui para a escola porque tinha que cuidar dos meus irmãos mais novos". \\
\hline M2 & $\begin{array}{l}\text { "por que eu as coisas eram tão dificeis que eu tinha } 10 \text { irmãos e nós não tinha nem chinelo para ir para } \\
\text { escola". }\end{array}$ \\
\hline M3 & "para ir casar". \\
\hline M4 & "tive que deixar os estudos para ir ajudar na luta do roçado". \\
\hline M5 & "para ir trabalhar." \\
\hline M6 & "para ir trabalhar em casa de família". \\
\hline M7 & "por que eu não tinha interesse de estudar". \\
\hline M8 & "para ir trabalhar no roçado”. \\
\hline M9 & "para ir trabalhar". \\
\hline M10 & "para trabalhar". \\
\hline M11 & "para ir trabalhar". \\
\hline M12 & "por que eu não gostava de estudar aí minha mãe me tirou”. \\
\hline
\end{tabular}

Nessa mesma pergunta, diante da análise dos dados, foi constatado que uma das participantes teve que abandonar os estudos para casar e se tornar dona do lar, nesse sentido essa questão coincide com os estudos de (PERROT, 2007), ao afirmar que isso se deve a uma construção social que foi sendo definida em cada sociedade e que exprime os estereótipos sobre o papel da mulher.

Através das falas podemos constatar que a relação de submissão e pobreza torna-se um fator predominante para que o processo de alfabetização não ocorresse, visto que a oportunidade que se existia naquele dado momento não influenciava para tomadas de decisões que focassem o estudo como fonte conhecimento e futuro meio de renda familiar, pois os pais das pesquisadas viveram em uma época em que o estudo não era prioridade devido a fatores diversos, inclusive o de trabalhar para sobreviver, sendo estes analfabetos e valorizavam o trabalho como prioridade, uma vez que a única forma de sustentar seus filhos era colocá-los (crianças ou jovens) para ajudarem em todas as atividades possíveis, sendo este um dos fatores que induziu o afastamento dessas mulheres na escola.

Sobre o tempo em que estas ficaram afastadas da escola vimos que, com exceção apenas de uma que ficou afastada apenas três anos, sendo assim 33,33\% passaram mais de 40 anos sem retornar os estudos, 25\% passaram trinta anos e 33,33\% passaram vinte anos (Quadro 4).

Ainda nesse mesmo contexto foi perguntado se sua busca pela escolarização através da EJA tinha ocorrido uma única vez, ou se elas já haviam tentado outras vezes sem obter os resultados almejados, nessa situação 58,33\% das participantes falaram que era a primeira vez que estavam nessa modalidade de ensino e 41,67\% já se matricularam nesse sistema entre duas a cinco vezes.

Portanto, o tempo de afastamento de sala de aula gira em torno de 20 a 40 anos, com exceção de uma que só ingressou na escola aos 43 anos de idade, a maioria das participantes estão frequentando a turma de EJA pela primeira vez, perante esses dados podemos perceber que mesmo diante nosso contexto atual, muitos fatores internos e externos prejudicam para as permanências destas mulheres no processo de escolarização.

Tais informações que nos remete aos estudos realizados pela Unesco (1997), onde apontam que: 
A igualdade de oportunidades em todos os aspectos ligados à educação é indispensável para permitir que as mulheres de todas as idades contribuam plenamente com a sociedade e para a solução dos múltiplos problemas enfrentados pela humanidade. Quando isoladas socialmente, sem acesso ao conhecimento e à informação, as mulheres estão excluídas da tomada de decisões no seio da família, da comunidade e da sociedade em geral, e são donas apenas, muito parcialmente, de seu próprio corpo e destino. Os sistemas de educacionais deveriam, portanto, combater obstáculos que impedem de ter acesso a recursos intelectuais, fornecendo-lhes meios de participar plenamente das transformações sociais. (UNESCO, 1997, p. 42).

Sobre as matriculas, tais dados nos remete ao Censo 2010 no Brasil, onde afirma que as mulheres continuam com taxas de analfabetismo menores que os homens, contudo essa tendência desaparece no grupo de 60 anos ou mais, fazendo-nos refletir que tais mulheres tiveram maiores dificuldades de se alfabetizar devido ao contexto histórico no qual estavam inseridos, os dados também revelam o quanto muitas destas, mesmo depois de regressarem os estudos por vezes tiveram que abandoná-los novamente por diversos fatores, uma vez que estas enfrentam uma dupla ou até tripla de jornada de trabalho para poderem se fazer presentes na sala de aula.

Nesse sentido, Andrade (2008) afirma que as cobranças em relação às mulheres são grandes e competir com os homens por escolarização, trabalho e visibilidade social, demanda grande esforço e habilidades que mulheres pobres, geralmente não dispõem, assim comprova-se mais uma vez o quanto a presença feminina luta para conseguir se sobressair em meio a uma sociedade excludente e machista.

Ao tratar das dificuldades existentes para regressar aos estudos, as pesquisadas afirmaram que $33,33 \%$ dos seus parceiros não apoiam sua escolha pelos estudos, outro aspecto que dificulta a estabilidade dessas alunas em sala de aula, se dá por conta do cansaço físico e mental que estas têm que superar para se fazerem presente na sala de aula representado por $(66,66 \%)$ (Quadro 4$)$.

Tais resultados reafirmam mais uma vez o quanto vivemos em uma sociedade injusta e desigual, uma vez que tabulasse que a luta por direito de igualdade de gênero está em ênfase, no entanto, omitem-se as demais atribuições exercidas pela força feminina no correr diário fator esse que interfere negativamente na permanência dessas mulheres no âmbito educacional e além de vivenciar todos esses aspectos ainda nos deparamos com um modelo de vida patriarcal e arcaico onde os esposos se encontram no direito de manipular e determinar todas as ações a serem exercidas por suas esposas.

Quadro 4. Respostas das mulheres pesquisadas quanto às dificuldades enfrentadas para voltar a estudar. Queimadas-PB. 2019

\begin{tabular}{|c|c|}
\hline Pesquisadas & Falas \\
\hline M1 & "meu marido não queria, ai minha vizinha convenceu ele a deixar”. \\
\hline M2 & "à falta de coragem, porque trabalhava o dia todo ai no final tava sem coragem”. \\
\hline M3 & "meu marido não permitia”. \\
\hline M4 & "enfrentar o cansaço de todo dia”. \\
\hline M5 & "encontrar força de vontade para vir para a escola”. \\
\hline M6 & "trabalhava o dia todo, ai de noite já estava sem coragem, mas minha patroa me motivou”. \\
\hline M7 & "aguentar as piadinhas do meu marido, ele não queria que eu estudasse”. \\
\hline M8 & "ter que trabalhar o dia todo e porque tenho muitos filhos". \\
\hline M10 & "o medo de ir para a escola sozinha, hoje em dia tá muito perigoso para mulher andar só". \\
\hline M11 & "meu sobrinho que mora comigo não queria que eu estudasse”. \\
\hline M12 & "porque eu sabia que aqui não teria pessoas da mesma idade que eu”. \\
\hline
\end{tabular}


Nesse sentido nossa pesquisa coincide com as falas de Rosemberg (2001), quando diz que a comparação de homens e mulheres em termos de acesso à educação formal no Brasil revela a existência de oportunidade e barreiras equivalentes em função da origem econômica e de igualdade de oportunidade e permanência educacional para os sexos.

Diante de tantas lutas ao nos remeter a questão das maiores dificuldades enfrentadas para fazer parte do processo de escolarização, as falas nos mostram que estas mulheres perpassaram e ainda passam por muitos obstáculos que estão sendo superados aos poucos. Assim é evidente que o processo de escolarização na vida dessas mulheres se procede através de muitos desafios e que esta não ocorre de forma sutil, uma vez que, grandes são as dificuldades, visto que elas demonstram sofrer com elementos de injustiça, opressão, discriminação, subordinação, preconceito pelos quais foram submetidas em relação à questão de gênero imposta pela sociedade, pois:

Os homens conscientes de que são detentores de uma autoridade que lhes é conferida pela sociedade patriarcal, os homens a exercem de forma irracional, não com autoridade, mas com autoritarismo, provocando a apatia pela destruição da estima ou uma revolta latente. (CARVALHO apud BOSI, 2004, p. 45).

Foi possível perceber alguns elementos são direcionados através do estado de "poder" que os indivíduos do sexo masculino exerciam e por vezes ainda exerce para com as pessoas de sexo feminino. Tal afirmação concorda com Bordieu (1998), uma vez que socialmente e historicamente, o poder de autonomia está nas mãos dos homens, esse poder seria mais difícil de ser alcançado pelas mulheres, por acreditarem que a mulher foi destinada somente para atividades domésticas e para criar filhos.

Nessa trajetória em voltar a estudar, além de enfrentar as regras imposta por uma sociedade historicamente machista, estas se deparam com um problema comum a todas, que é enfrentar o cansaço físico e mental de uma rotina diária, uma vez que estas são esposas, mães, chefe da casa, além de exercerem diferentes cargos diante a sociedade.

Falta estímulo por parte das mulheres mais jovens que frequentam essa modalidade de ensino, uma vez que estas sabem que na maioria dos casos vão se deparar com pessoas com idade muito maior que a sua e que possuem objetivos e pensamentos muito divergente dos seus. Haddad e Di Pierro (2000) afirmam que temos um novo tipo de exclusão educacional: antes as crianças não podiam frequentar a escola por ausência de vagas, hoje ingressam, mas não aprendem e dela são excluídos antes de concluir os estudos com êxitos, tais pensamentos corroboram com a realidade encontrada, pois, houve uma aluna que não conseguiu concluir a série na idade "ideal" e por esse motivo foi remanejada para a turma de EJA.

Sobre o que lhes motivaram a regressar aos estudos $83,33 \%$ responderam que foi a necessidade de aperfeiçoar sua aprendizagem no processo de leitura e escrita, sendo que destas $(16,66 \%)$ acrescentaram em suas respostas que além de buscar maiores conhecimentos, a escola atua como um espaço acolhedor e terapêutico, onde elas conseguem se "libertar" por algumas horas dos problemas diários, nessa mesma pergunta 8,33\% além de mencionar os aspectos já citados, acrescentou que esse processo irá ajudar a melhorar seu desempenho no trabalho.

Sendo assim, nota-se o almejo das mulheres em querer mudar o rumo de sua história, em ir à busca de novos horizontes e por estarem lutando por uma perspectiva de vida de melhor qualidade. 
Seguindo essa ordem de raciocínio, nossos estudos coincidem com os de Nogueira (2006) no qual fomenta que se tornam necessárias as variadas discussões sobre a educação feminina e a implementação de políticas que tenham como objetivo exterminar qualquer tipo de discriminação, principalmente no sentido da educação e do acesso a ela. Nesse sentindo faz-se cada vez mais evidente a necessidade de investir no acesso e permanência dessas mulheres no âmbito educacional, buscando assim possibilitar um estado de equidade entre os sexos, nesse sentindo:

A prioridade mais urgente é melhorar a qualidade e garantir o acesso à educação para meninas e mulheres, e superar todos os obstáculos que impedem sua participação ativa no processo educativo. Os preconceitos e estereótipos de qualquer natureza devem ser eliminados da educação. (UNESCO, 1997, p. 14).

Ao abordar quais os objetivos e expectativas que estas buscam, constatamos que 50\% das participantes almejam enriquecer seus conhecimentos e aumentar seus níveis de aprendizagem, objetivando um melhor desempenho pessoal diante a sociedade, 16,66\% informaram o desejo de frequentar uma universidade, além das questões já citadas também obtivemos como resposta o anseio em tornar-se escritora, sendo este representado por um porcentual de $(8,33 \%)$ das pesquisadas.

Ficou evidente que essas mulheres buscam avançar nos estudos a fim de viver ativamente em uma sociedade com direito de expressão livre e com finalidade de mudar o rumo de suas vidas.

Ainda, em relação às falas das pesquisadas, é notável o quanto elas buscam uma mudança de comportamento e de postura através do processo de escolarização, é nesse sentido que Giroux (1998) aponta que a alfabetização crítica se torna precondição para o empoderamento individual e social, portanto, é notável que na busca por seus anseios elas descubram que através da aprendizagem escolar as dificuldades vão sendo superadas e isto estimula a elevação da autoestima e consequentemente a realização pessoal e social, sendo assim:

A escola tem um papel importante nessa questão de desconstrução dos padrões culturais idealizados e reproduzidos na sociedade, sendo um espaço que permite discussões sobre novas formas de olhar para as mulheres e lhes permitir a ocupar seu espaço e realizar suas escolhas. Hoje a mesma escola que forma indivíduos para a sujeição e a submissão, pode, por meio da conscientização, emancipar e libertar. (POGGIO, 2012, p. 97).

Ao questionar quais fatores influenciam para sua permanência em sala de aula obtivemos os seguintes argumentos: 58,33\% mencionaram que o desejo em ir à busca de novos conhecimentos é fator primordial para que elas estejam com frequência ativa diariamente na escola, também foi mencionado o desejo de cuidar mais da mente e da saúde, sendo este representado por (8,33\%), nessa mesma indagação $33 \%$ afirmou que permanecer com os estudos contribui para que esta sirva melhor a igreja que frequenta, além desses fatores, também foi mencionado por 33\% que deseja permanecer na escola, pois anseia avançar nos estudos e poder acompanhar o processo de escolarização dos colegas que possuem a mesma idade que a sua.

Desta maneira a EJA vem se apresentando como uma modalidade que proporciona ao seu alunado condições de superação da exclusão social para com as mulheres que não puderam contemplar os estudos no ensino regular, em concordância Bruschini (2007) contempla que o ingresso das mulheres no mercado de trabalho é influenciado pelo avanço da escolaridade das brasileiras, que estão tendo cada vez mais acesso à educação, sendo 
assim é notório que a continuidade ou o retorno aos estudos modifica positivamente a qualidade de vida das mulheres, pois além da aquisição dos conhecimentos, estas elevam seus desejos de evolução e crescimento pessoal.

Em nossos questionamentos buscamos descobrir se a escola tem alterado a qualidade de vida das pesquisadas diante ações a serem realizadas perante a sociedade, nesse aspecto 41, 66\% mencionaram que através do processo de escolarização o medo e a vergonha que sentiam em expor seus pensamentos e ideias em público foram sanadas, vindo a sentir maior confiança em expor suas falas. Seguindo essa linha de pensamento também foi mencionado que através dos estudos conseguiram elevar sua autoestima diante a vida pessoal e social, vindo esse aspecto a ser representado por um total de $(25,00 \%)$ e 33,33\% afirmaram que através dos estudos não precisam do auxílio de terceiros para resolver situações que envolvam o ato de ler e escrever (Quadro 5).

Portanto, diante os dados podemos deduzir que a vida dessas mulheres fora e é modificada a cada dia depois do processo de escolarização, visto que estas encontrassem em um processo de superações e modificações que influenciam para que o empoderamento pessoal ocorra em sua vida diária, pois através de pequenas ações rotineiras elas adquirem um espaço que antes não podiam vivenciar.

Quadro 5. Respostas das mulheres pesquisadas em relação se a escola alterou sua qualidade de vida diante a sociedade. Queimadas-PB. 2019

\begin{tabular}{|c|c|}
\hline Pesquisadas & Falas \\
\hline M1 & "antes de estudar eu tinha vergonha de tudo, até de falar, hoje não tenho mais vergonha de nada”. \\
\hline M2 & $\begin{array}{c}\text { "mudou muito, agora já sei ir para os cantos sozinha e já sei o que vou fazer, não preciso da ajuda de } \\
\text { outras pessoas para sair". }\end{array}$ \\
\hline M3 & “minha vida mudou, antes eu tinha vergonha de falar com as pessoas, hoje não tenho”. \\
\hline M4 & $\begin{array}{c}\text { "minha vida agora é outra, agora em todo canto que chego já não preciso colocar o dedo, hoje raças a } \\
\text { Deus já sei assinar meu nome”. }\end{array}$ \\
\hline M5 & "Sim, hoje eu sou uma mulher muito mais desenrolada". \\
\hline M6 & "a escola me ajudou muito, hoje sei ler as placas, receita, a biblia". \\
\hline M7 & “a escola mudou muito minha vida, eu já criei um animo maior para correr atrás de tudo que eu quero”. \\
\hline M8 & “depois da escola eu sou outra mulher, já sei me virar sozinha em muitas coisas". \\
\hline M9 & $\begin{array}{c}\text { "depois da escola não tenho mais medo de falar o que eu quero, não preciso mais ficar calada de cabeça } \\
\text { baixa”. }\end{array}$ \\
\hline M10 & $\begin{array}{c}\text { "antes eu precisava dos outros para fazer tudo comigo, eu tinha medo de ir só, depois da escola eu já sei } \\
\text { me virar sem precisar perturbar os outros para ir comigo". }\end{array}$ \\
\hline M11 & $\begin{array}{c}\text { "depois que tô estudando, eu já sei viajar sozinha, faço compras sozinha, sei tirar meu trocadinho no } \\
\text { banco”. }\end{array}$ \\
\hline M12 & $\begin{array}{c}\text { "depois que estou estudando com essa professora eu percebo que não preciso ter vergonha de falar o que } \\
\text { eu acho que é certo". }\end{array}$ \\
\hline
\end{tabular}

Diante tais afirmações é notável em todas as falas a presença do empoderamento, sendo este decorrente de ações realizadas através do processo de escolarização, pois possuir o domínio da leitura e escrita favorece a realização de atividades que para muitos podem ser consideradas simples, como por exemplo: fazer compras, sacar um dinheiro, pegar um ônibus, mas que até então não estas não conseguiam realizar, em concordância Lisboa (2008) contempla que empoderamento é o mecanismo pelo qual as pessoas, as tomam controle de seus próprios assuntos, de sua própria vida, de seu destino, tomam consciência da sua habilidade e competência para produzir, criar e gerir, conquistando assim o direito de exercer sua autonomia e sendo protagonista dos seus objetivos.

Dando continuidade aos nossos estudos através das coletas de informações, objetivamos compreender se a famílias das pesquisadas contribuem para que estas permaneçam com suas atividades escolares, nesse sentindo 
$50 \%$ afirmaram que a família apoia no retorno para a escola e que estimulam para sua permanência no espaço escolar, cabendo aqui mencionar que nessas respostas "os(as) filhos (as)" representam os membros que mais influenciam nessa ação, obtivemos também como respostas a rejeição dos conjugues em relação a permanecia e continuidade aos estudos, sendo aqui representado pelo total de (33,33\%), mas apesar desse número que representa a rejeição dos parceiros, também somamos a quantia de 16,66\% que antes não apoiavam as escolhas de suas companheiras em voltar a estudar e que hoje mudaram seus comportamentos e aceitam, sem criticar tais ações (Quadro 6).

Pode-se inferir que a metade das mulheres envolvidas nesse estudo possui apoio de seus familiares, no qual em grande maioria advém de seus filhos, fator esse que nos faz perceber que tais filhos reconhecem as lutas que estas mulheres perpassam e que estes apoiam para que estas possam viver de melhor forma, no entanto, também percebemos que apesar destas terem apoio dos filhos boa parte não possui apoio de seus esposos, nos remetendo a pensar no poder de hierarquia do contexto social do qual este advém, onde era imposto que as atividades femininas eram para suprirem apenas os afazeres domésticos, conjugais e maternais.

Quadro 6. Respostas das mulheres pesquisadas em relação à contribuição da família para sua permanência na escola. Queimadas-PB. 2019

\begin{tabular}{|c|c|}
\hline Pesquisadas & Falas \\
\hline M1 & "eles sempre me mandam estudar”. \\
\hline M2 & "meus filhos me apoiam muito, sempre mandam eu vir para escola”. \\
\hline M3 & "meu filho me manda estudar para eu ser uma professora um dia”. \\
\hline M4 & "antes meu marido reclamava muito, hoje eu dei um "rela” nele e pronto". \\
\hline M5 & "minha familia crítica minha ida a escola por causa da minha idade”. \\
\hline M6 & "hoje meu marido já não reclama mais”. \\
\hline M7 & "minha filha me dá força, mas meu namorado reclama muito”. \\
\hline M8 & "meus filhos me motivam, mas meu marido não”. \\
\hline M1 & "meus filhos me apoiam, mas minha mãe não". \\
\hline M11 & "meus filhos apoiam, mas meu marido não gosta muito”. \\
\hline M12 & "meu sobrinho não quer que eu estude, mas eu não tô nem ai para o que ele diz". \\
\hline
\end{tabular}

Diante tais apontamentos, nota-se um grande avanço da família em incentivar a ida destas mulheres ao campo de estudo, no entanto, Mosadale (2005) salienta que:

O empoderamento somente pode ser alcançado pelo indivíduo que quer se empoderar. Mesmo que um terceiro indivíduo possa criar uma situação ou condição favorável para que isso se concretize, somente o interessado pode realizar a ação. Portanto, todos os sinônimos e os significados da palavra empoderamento apresentam a capacidade de o indivíduo ter autonomia e controle nas suas ações e iniciativas, assumindo seu próprio destino. (MOSADELE, 2005, p. 254).

Ao indagar se o processo de escolarização era mais difícil entre pessoas do sexo masculino ou feminino, mais da metade das pesquisadas $66,66 \%$ afirmaram que a busca pelos estudos é mais difícil para as mulheres, uma vez que para elas foi atribuída uma ampla diversidade de afazeres diários (limpar, cozinhar, cuidar dos filhos, e por vezes, ter um emprego remunerado). Nessa mesma indagação além de todas as tarefas acima citadas, também foi mencionado como grande empecilho na busca dos estudos a insatisfação dos maridos diante as escolhas adotadas por suas parceiras. Em contrapartida, 33,33\% mencionaram que os homens sentem maior dificuldade, visto que 
estes trabalham o dia inteiro fora de casa e não possuem determinação suficiente para ir à busca dos estudos, além desses fatores também foi mencionado que o homem sente vergonha de buscar conhecimentos pedagógicos (Quadro 7).

Quadro 7. Respostas das mulheres pesquisadas a respeito do processo de escolarização ser mais difícil entre homens ou mulheres e o porquê de sua resposta. Queimadas-PB. 2019

\begin{tabular}{|c|c|c|}
\hline Pesquisadas & $\begin{array}{c}\text { Estudar é } \\
\text { mais difícil } \\
\text { para homem } \\
\text { ou mulher? }\end{array}$ & Falas das pesquisadas justificando as respostas \\
\hline M1 & Mulher & $\begin{array}{l}\text { "porque muitas vezes os maridos não querem deixar } \\
\text { as mulheres virem para a escola" }\end{array}$ \\
\hline M2 & Mulher & $\begin{array}{l}\text { "porque a mulher trabalha muito e no fim do dia tá } \\
\text { cansada" }\end{array}$ \\
\hline M3 & Mulher & "porque nós temos uma vida muito corrida" \\
\hline M4 & Mulher & $\begin{array}{l}\text { "por que temos que fazer tudo para poder vir para a } \\
\text { escola" }\end{array}$ \\
\hline M5 & Mulher & $\begin{array}{l}\text { "porque a mulher trabalha muito, já o homem não } \\
\text { tem interesse" }\end{array}$ \\
\hline M6 & Homem & $\begin{array}{l}\text { "porque o homem tem mais vergonha de vir para a } \\
\text { escola" }\end{array}$ \\
\hline M7 & Homem & "porque homem não se interessa para estudar" \\
\hline M8 & Homem & "porque eles são preguiçosos" \\
\hline M9 & Mulher & $\begin{array}{l}\text { "porque temos uma vida corrida, mas mesmo assim } \\
\text { estou aqui, firme e forte" }\end{array}$ \\
\hline M10 & Homem & "porque trabalha fora de casa em firma \\
\hline M11 & Mulher & "porque a gente trabalha muito" \\
\hline M12 & Mulher & "porque a mulher trabalha mais" \\
\hline
\end{tabular}

Diante dessas respostas, pode-se afirmar que mais da metade das mulheres afirmam que a dificuldade seja maior para as mulheres e isso nos instiga a refletir que apesar delas mesmas considerarem uma tarefa árdua e difícil em frequentar a escola, mesmo assim elas são público determinante nas salas de aulas, fator esse que nos remete a mencionar o quanto as mulheres são guerreiras e determinadas em busca de seus ideais e que mesmo diante uma sociedade excludente estas não se impõe aos pressupostos determinados pelo contexto.

Sabemos da vasta jornada de trabalho que as mulheres enfrentam para conseguir conciliar todos os cargos a que lhes foram atribuídos, restando assim um cansaço e uma dificuldade maior para concretizarem seus objetivos, principalmente quando este se refere à continuidade dos estudos, confirmando o que descreveu Piovesan (2001):

Ao longo da história, foram atribuídos, às mulheres, os cuidados com os filhos e o marido, além de tarefas domésticas; e, aos homens, foi destinada a esfera pública. Essa divisão de responsabilidades com a casa ainda é predominante, fazendo com que as mulheres tenham sobrecarga de atividades após o horário de trabalho. (PIOVESAN, 2011).

Ao perguntarmos se a busca pelo processo de escolarização é maior entre as mulheres ou homens, 91,66\% afirmaram que as mulheres são público maior nas salas de aula, uma vez que estas querem recompensar o tempo que ficaram sem estudar, e que não querem perdem as oportunidades que surgem diariamente para seu crescimento pessoal e profissional, em suas falas elas se caracterizam como mulheres fortes, guerreiras e corajosas e que a cada dia estão conseguindo liderar os ambientes que frequentam (seja familiar ou profissional), nesse mesmo contexto apenas 8,33\% afirmou que acredita ser igual à presença de ambos os sexo nas salas de aula (Quadro 8). 
É notável que estas mulheres reconheçam suas trajetórias de vida como fonte de superação a cada amanhecer e que estas almejam constantemente modificar suas histórias, buscando meios para evoluírem constantemente, nesse aspecto, percebe-se que tais mulheres reconhecem a importância dos estudos para sua vida pessoal e social, fazendo com que estas busquem constantemente maiores formações escolares.

Quadro 8. Respostas das mulheres pesquisadas sobre a busca por escolarização ser maior entre homens ou mulheres. Queimadas-PB. 2019

\begin{tabular}{|c|c|}
\hline Pesquisadas & Falas \\
\hline M1 & "nós mulheres buscamos mais, porque temos que aproveitar a oportunidade de poder estudar”. \\
\hline M2 & "nós mulheres, porque queremos mudar de vida”. \\
\hline M3 & "nós mulheres, porque temos mais interesse e mais coragem”. \\
\hline M5 & "nós mulheres, porque a gente se interessa mais... a escola acaba sendo um lugar para se distrair”. \\
\hline M6 & "as mulheres, porque as mulheres lutam mais, as mulheres estão no comando”. \\
\hline M7 & "as mulheres são mais guerreiras e atenciosas”. \\
\hline M8 & "nós mulheres, porque somos mais fortes e temos mais força de vontade”. \\
\hline M9 & "a mulher é mais guerreira, não desiste fácil não”. \\
\hline M10 & "as mulheres são mais guerreiras”. \\
\hline M12 & "as mulheres procuram mais, os homens são preguiçosos". \\
\hline
\end{tabular}

Continuando o roteiro de perguntas foi questionado como a escola poderia facilitar a busca das mulheres pelo processo de escolarização e 66,66\% mencionaram que se fosse liberado um transporte para conduzi-las até a escola seria um bom investimento, uma vez que todas estudam no período noturno e este é muito perigoso para elas circularem nas ruas, além desse fator também foi mencionado que a escola poderia oferecer ao público ações diferenciadas que estimulassem ainda mais a busca pelos estudos, sendo essa fala representada por $(16,66 \%)$ das participantes, foi mencionado por $8,33 \%$ que deveria ser realizado palestras ou reuniões para os homens da localidade onde a escola está situada para que estes mudassem seus pensamentos e apoiassem a vindas das mulheres para a escola, por fim 8,33\% demonstram satisfeita com as ações já existentes e não sugeriu nenhuma mudança (Quadro 9).

Quadro 9. Respostas das mulheres pesquisadas sobre como a escola poderia facilitar a busca das mulheres pelo estudo. Queimadas-PB. 2019

\begin{tabular}{|c|c|}
\hline Pesquisadas & Falas \\
\hline M1 & "talvez se fizesse uma reunião para os maridos deixarem suas mulheres virem para a escola". \\
\hline M2 & "a prefeitura poderia colocar um carro para nos trazer". \\
\hline M3 & "para mim tá tudo bom". \\
\hline M4 & "a escola poderia nos motivar mais". \\
\hline M5 & "se tivesse um carro para nos trazer era melhor, porque a noite é muito perigoso andar só mulher". \\
\hline M6 & "se tivesse pelo menos uma van para nos trazer seria muito bom". \\
\hline M7 & "poderia ter um carro para nos trazer". \\
\hline M8 & "era bom um carro para os trazer". \\
\hline M9 & "era bom que tivesse mais reunião para animar o povo a estudar". \\
\hline M10 & "se tivesse um carro acho que viria mais pessoas para a escola". \\
\hline M11 & "se a gente tivesse pelo menos um carro para nos trazer para a escola, já ajudaria muito, porque nessa \\
\hline M12 & época de chuva dá uma preguiça danada". \\
\hline
\end{tabular}


Mais da metade das pesquisadas apresentam argumentos que podem facilitar sua atual trajetória escolar, fator esse bastante relevante se olharmos sobre a questão da participação ativa em comunidade, nesse contexto Soares (2006) menciona:

A questão relacionada à educação da mulher, em especial a alfabetização, vem ocupando espaço privilegiado, desde a última década do século passado, na agenda das grandes conferências internacionais e dos organismos nacionais [...] como fruto das reivindicações a valorização da mulher e o reconhecimento dos seus direitos, a condição feminina passou a constituir tema obrigatório na agenda internacional da Organização das Nações Unidas- ONU. (SOARES apud NOGUEIRA, 2006).

Sobre como a escola poderia contribuir na vida dessas mulheres, nos deparamos com respostas que nos conduz a refletir sobre os conteúdos programáticos por essa modalidade de ensino e se estes suprem com as reais necessidades das educandas, pois:

A estrutura curricular e os conteúdos oferecidos na escola são organizados a partir de concepções, valores e ideias de um universo bem distante da realidade que os educandos da EJA vivenciam. Isso dificulta a apropriação dos conhecimentos oferecidos porque está distante daquilo que experimentam em seu cotidiano, não facilitando o processo cognitivo. (LOPES, 2011, p. 101).

Ao solicitarmos que falassem algo para as mulheres que abandonaram os estudos obtivemos em 100\% das falas a importância do ato de estudar, a satisfação que é ser uma pessoa alfabetizada, mencionaram também que na escola elas têm a oportunidade de se expressarem, fizeram apelos para que elas não desistam diante as dificuldades, que não se acomodem em frente a uma televisão e buscaram repassar a informação que os estudos fazem bem para a mente e para o corpo e além destas afirmações elas argumentam que através do estudo tudo podem fazer (Quadro $10)$.

Quadro 10. Respostas das mulheres pesquisadas em relação ao que diriam para outras mulheres que abandonaram os estudos. Queimadas-PB. 2019

\begin{tabular}{|c|c|}
\hline Pesquisadas & Falas \\
\hline M1 & "volte a estudar, estudar é a melhor coisa do mundo". \\
\hline M2 & "venha estudar porque é muito bom e serve para a memória”. \\
\hline M3 & "venha para a escola para aprender o que você não sabe”. \\
\hline M4 & "venha estudar, é muito bom ser uma pessoa alfabetizada”. \\
\hline M5 & "mulheres nós temos que lutar por nossos objetivos, não podemos temer, porque os tímidos não \\
\hline M6 & conseguem nada, lutem”. \\
\hline M7 & "lutem e corra atrás, porque a vida não é fácil, temos que ter vontade”. \\
\hline M8 & "venha estudar, na escola a gente é bem-vinda”. \\
\hline M9 & "pare de perder tempo, venha para a escola". \\
\hline M10 & "venham para a escola, não percam tempo, não vivam no pé da televisão". \\
\hline M11 & "venham para a escola para aprender mais”.. \\
\hline M12 & Venham estudar, estudar é muito importante”. \\
\hline
\end{tabular}

Nesse sentido, Poggio (2012) aponta:

A escola tem um papel importante nessa questão de desconstrução dos padrões cultuais idealizados e reproduzidos na sociedade, sendo um espaço que permite discussões sobre novas formas de olhar para as mulheres e lhes permitir ocupar seu espaço e realizar suas escolhas. Hoje a mesma escola que forma indivíduos para a sujeição e submissão, pode, por meio da conscientização, emancipar e libertar. (POGGIO, 2012, p. 97). 
Nessa mesma questão, também é notável o quanto essas mulheres encontram-se com autoestima elevada, como elas dão ênfase ao processo de escolarização e o quanto este altera sua qualidade de vida, as falas das alunas é de suma importância para a análise dos nossos estudos, uma vez que nos remete a pensar o quanto estas mulheres encontram-se realizadas por estarem frequentando uma sala de aula, o quanto elas relacionam suas conquistas ao termo escolarização e o intenso convite para que mais mulheres consigam conquistar maiores espaços com autonomia e satisfação, libertando-se assim de "suas opressões".

Diante tais aspectos dados do IBGE (2012) apontam:

A participação da mulher no mercado de trabalho era apenas 35\%, já em 2003, o crescimento feminino foi de $40 \%$ a 45,3 em 2011. O percentual masculino, no mesmo período foi de $60,8 \%$ evoluindo para 63 em 2011. Esses índices são pequenos, levando em consideração que a população feminina é maior que a masculina no Brasil. Um fator determinante para esse crescimento é determinado pelo fato que as mulheres têm investido mais na escolaridade, nesse quesito elas estão em vantagem aos homens. As mulheres com mais de 11 anos de estudo compreendem um total de $51 \%$ enquanto os homens nas mesmas condições $38,4 \%$ no período de 2003. (IBGE 2012).

É perceptível que nos últimos tempos as mulheres estejam cada vez mais ocupando os ambientes escolares e esse fator é enriquecedor para a emancipação das mesmas, pois se imagina que através do processo escolar elas terão mais oportunidades de se expressar, de indagar, de conversar sobre diversos conteúdos, (inclusive sobre o contexto que marcam sua história), elas têm acesso a um público maior de pessoas, onde podem se comunicar e adquirirem maior domínio sobre determinado contexto, elas se alfabetizam e consequentemente esperasse que se tornem "sujeitos" letrados, para que possam adquirir maior autonomia em suas decisões.

Quando perguntamos se a família contribui de alguma forma para que elas permaneçam estudando, 66,66\% tem o apoio dos familiares, que sempre buscam incentivar e ajudar no que é possível para que estas se façam presentes na escola, também foi observado que algumas não possuem ajuda para a concretização dessa ação e que essa falta de apoio advém de seus companheiros, sendo aqui representado pelo total de (16,66\%), restando 16,66\% que demonstram em sua fala um empoderamento pessoal no qual afirmam serem autoras de suas próprias escolhas e que não são sujeitas as ordens de terceiros (Quadro 11).

Quadro 11. Respostas das mulheres pesquisadas em relação às contribuições ou não da família em relação aos estudos. Queimadas-PB. 2019

\begin{tabular}{|c|c|}
\hline Pesquisadas & Falas \\
\hline M1 & "minha família não dá palpite, na minha vida mando eu, nem meu marido manda mais em mim". \\
\hline M2 & "eles me ajudam, me mandam vir para a escola". \\
\hline M3 & "eles sempre me mandar vir para a escola". \\
\hline M4 & "não tenho motivação em casa, meu marido bebe muito e isso me atrapalha". \\
\hline M5 & "não permito que falem nada". \\
\hline M6 & "meu marido hoje já aceita minha ida a escola e não diz mais nada". \\
\hline M7 & "minha filha sempre manda eu focar nos estudas". \\
\hline M8 & "meus filhos sempre me mandam vir para a escola". \\
\hline M9 & "minha familia apoia". \\
\hline M10 & "eles me mandam vir para a escola". \\
\hline M11 & "se fosse pela vontade do meu sobrinho eu não vinha nunca". \\
\hline M12 & "minha mãe sempre manda eu vir para escola". \\
\hline
\end{tabular}


Mais da metade das pesquisadas encontram em seus familiares um apoio motivador para que estas consigam continuar e concretizar seus objetivos. Nesse sentido Andrade (2008) aponta que se antes, o lugar da mulher era em casa, para cuidar de afazeres domésticos e das crianças, hoje o lugar da mulher também é na escola, o fato da família apoiar as escolhas destas mulheres é bastante satisfatório, uma vez que ao frequentarem as aulas elas fortalecem a cada dia a ambição da concretização dos seus sonhos que por vezes foram banidas enquanto estas eram crianças ou adolescentes.

Nesse contexto, Borges (2009) afirma que a mulher brasileira está incluída na tendência global do fortalecimento, alcançando espaços aos quais não possuíam acesso anteriormente, pois, eram destinados aos homens, como por exemplo, o mercado de trabalho, os estudos e a política. Tais aspectos nos conduzem a refletir que apesar das dificuldades e limitações impostas, as mulheres aos poucos estão adquirindo espaço em meio social e que as adversidades vêm por meio a fortalecê-las fazendo com que as mesmas se empoderem de suas expectativas para continuarem com suas conquistas e adquirirem o estado de equidade tão almejado.

Ainda nessa mesma questão, é notável a presença nítida do empoderamento na fala de uma das alunas, haja vista que ela argumenta "minha família não dá palpite, na minha vida mando eu, nem meu marido manda mais (M1)”. Tal expressão nos instiga a refletir que esta advém de um processo imenso de submissão e sujeição, das quais esta já se desapegou e não se submete mais a tais situações.

Lisboa (2008) discorre que o empoderamento é o mecanismo pelo qual as pessoas, as organizações e as comunidades tomam controle de seus próprios assuntos, de sua própria vida, de seu destino, tomam consciência de suas habilidades e competência para produzir, criar e gerir. Nesse aspecto notamos que o processo de escolarização em consonância com a realidade de vida de cada um, influencia para o início de uma emancipação pessoal e consequentemente social que pode vir a favorecer na construção da autonomia do "sujeito".

Foi perguntado às alunas participantes se estas já haviam recebido alguma crítica por terem regressado aos estudos e de quem ouviu tais comentários: 91,66\% afirmaram já terem sido violentadas verbalmente por optarem pelos estudos, e que ouvira tais palavras de parentes ou vizinhos, continuando a análise dos dados desta questão apenas 8,33\% informou que nunca ouviu comentários (Quadro 12).

Quadro 12. Respostas das mulheres pesquisadas sobre palavra desmotivadora que ouviu por ter voltado a estudar e quem lhe disse. Queimadas-PB. 2019

\begin{tabular}{|c|c|c|}
\hline Pesquisadas & Falas & De quem \\
\hline M1 & "nunca me falaram nada, mas se falar eu corto logo”. & - \\
\hline M2 & "para que você vai pra escola? Você não aprende mais não. & Vizinhos \\
\hline M3 & "pra que estudar depois de velha”. & Vizinhos \\
\hline M4 & "para que a senhora ir para escola, já ta velha, não prende mais”. & Vizinhos \\
\hline M5 & "pra que tu vai pra escola, não aprende mais nada não”. & Irmã \\
\hline M6 & "papagaio velho não aprende a falar”. & Irmãos \\
\hline M7 & “o que você vai ver na escola, você não aprende nada mesmo”. & Mãe \\
\hline M8 & "só vai para escola para merendar”. & Vizinho \\
\hline M9 & "pra que você ir para escola, você não aprende nada mesmo”. & Vizinhos \\
\hline M10 & "papagaio velho não aprende a falar”. & Vizinhos \\
\hline M11 & "para que a senhora vai estudar, você não aprende mais”. & Sobrinho \\
\hline M12 & "você vai pra que? Você não aprende mais”. & Vizinho \\
\hline
\end{tabular}


Oliveira (2017) enfoca que o preconceito em relação ao gênero dentre os/as alunos/as da EJA aparece em falas como essa: "lugar de mulher é em casa, cuidando dos filhos e dos maridos e não na escola", discurso recorrente entre a maioria dos homens que estão nas salas de aula e suas mulheres em casa. Nesse aspecto, notamos o quanto as mulheres ainda sofrem discriminações por irem a buscas de melhoria de vida (ARANHA, 2006) diz:

Na comunidade primitiva a mulher desempenhava um papel social relevante, participando das atividades coletivas da tribo. Mesmo que já houvesse divisão de tarefas, essas eram complementares, não de subordinação. Quando surgiu a propriedade privada, a mulher foi confinada ao mundo doméstico e subordinada ao chefe da família [...] De participante da produção social, a mulher viu-se reduzida à função de reprodutora e encarregada da educação dos meninos até os sete anos de idade, enquanto as meninas permaneciam confinadas ao lar até o casamento. (ARANHA, 2006, p. 32).

Tal situação reafirma o contexto arcaico, preconceituoso e machista do qual advimos e no qual ainda estamos inseridos, onde muitos asseveram que a mulher deveria permanecer em estado de submissão e que estas deveriam dar-se por satisfeita com as ações impostas pela sociedade, tais apontamentos nos remete a reflexão de que vivemos em um mundo em que o crescimento pessoal do próximo causa rejeição e temor, sendo talvez esse um dos fatores que conduzam a população a negar e criticar o crescimento e bem estar dessas mulheres que almejam com a escolarização mudar o rumo de suas histórias de vida, assim Melo (2011) aponta que as mulheres estão mudando seu comportamento para competir em igualdade com os homens. Elas vêm conquistando isso através da educação, capacitando-se para o mercado de trabalho; e, de fato, há na sociedade uma geração de mulheres que lutam por reconhecimento e valorização.

Ao perguntarmos as participantes se já receberam palavras que lhes motivassem a continuar com os estudos e de quem as ouvira, $100 \%$ afirmaram que já receberam belas mensagens inspiradoras que lhes incentivam cada vez mais a investir no processo escolar e que estas advêm de parentes, vizinhos e patroas (Quadro 13).

Quadro 13. Respostas das mulheres pesquisadas sobre palavras motivadoras que ouviu por ter voltado a estudar e quem lhe disse. Queimadas-PB. 2019

\begin{tabular}{|c|c|c|}
\hline Pesquisadas & Falas & De quem \\
\hline M1 & "estude para um dia ser uma advogada”. & Irmã \\
\hline M2 & "nunca abandone os estudos”. & Irmã e sobrinhos \\
\hline M3 & "nunca desista de lutar”. & Amigas da atividade física \\
\hline M4 & "nunca desista, pois a escola vai trazer sua felicidade”. & Vizinhos \\
\hline M5 & "vá em frente, um dia você vai se formar”. & Patroa \\
\hline M6 & "parabéns por não desistir”. & Irmãos \\
\hline M7 & "você pode tudo”. & Patroa \\
\hline M8 & "parabéns, você é muito corajosa”. & Irmã \\
\hline M9 & "continue lutando, você consegue”. & Vizinhos \\
\hline M10 & "parabéns por estar aprendendo, já que não aprendeu quando era criança”. & Mãe \\
\hline M11 & "vá em frente que estudar é bom”. & Vizinhos \\
\hline M12 & "não desista que você aprende”. & Mãe \\
\hline
\end{tabular}

As respostas apontam que apesar de tantas batalhas, desafios e sofrimentos, estas mulheres de alguma forma encontram meios para aumentar seus anseios, sejam estes através de palavras inspiradoras ou por próprias ações advindas do contexto em que estão inseridas, nesse sentido a Declaração de Jomtien, enfoca que "A prioridade mais urgente é melhorar a qualidade e garantir o acesso à educação para meninas e mulheres, e superar 
todos os obstáculos que impedem sua participação ativa no processo educativo. Os preconceitos e estereótipos de qualquer natureza devem ser eliminados da educação". (UNESCO, 1997, p. 4).

Tais apontamentos revigoram os pensamentos a respeito da presença feminina em todo contexto social, inclusive no escolar, fazendo-nos perceber que aos poucos o direito de igualdade vem sendo compreendido e que lentamente a sociedade percebe que fizesse necessária a presença feminina em todas as esferas, e não seria diferente área de escolarização, pois:

\begin{abstract}
A alfabetização crítica se torna precondição para o empoderamento individual e social, portanto, o sujeito inserido nesse processo precisa acima de tudo tomar consciência de que a alfabetização é e pode ser um instrumento para a estruturação de uma nova visão a fim de desenvolver suas perspectivas histórias e de perceber-se como partícipe das lutas em prol de mudanças. (HENRY, 1988, p. 64).
\end{abstract}

De acordo com Drucker (1996) as mulheres têm um estilo próprio de liderança, possuem bom humor e agem com humildade, tratando com igualdade as pessoas, são claras e objetivas em suas metas. Assim, é possível afirmar o quanto a conquista pelo direito de igualdade é atuante e que aos poucos o reconhecimento feminino vai emergindo em nosso meio, o que se faz necessário é exercemos a luta pela equidade entre os gêneros.

Pode-se perceber que elas entendem por empoderamento a ato de ser livres para fazerem escolhas sem necessitar se submeter à decisão de alguém, é ser capaz de enfrentar os obstáculos sem temê-los, não precisar de liberação para realizar qualquer ação que envolva sua vida pessoal, é ter um salário, é conversar com quem sentir vontade, é estudar, é ser independente (Quadro 14), nesse aspecto Léon (1997) afirma que o empoderamento inclui a mudança individual e a ação coletiva para alterar os processos e estruturas que reproduzem a posição subordinada da mulher.

Quadro 14. Respostas das mulheres pesquisadas sobre o que é ser uma mulher empoderada. Queimadas-PB. 2019

\begin{tabular}{|c|c|}
\hline Pesquisadas & Falas \\
\hline M1 & "é poder fazer o que quiser". \\
\hline M2 & "poder passear para onde quiser, gastar nosso próprio dinheiro". \\
\hline M3 & "é poder ir onde eu quiser e conversar com quem eu quiser”. \\
\hline M4 & "poder ir para onde quiser e fazer o que quiser". \\
\hline M5 & "a gente sair sem ninguém impedir”. \\
\hline M6 & "é fazer o que quer, não temer nada e enfrentar todos os obstáculos “. \\
\hline M7 & "é trabalhar, ter meu salário e que poder fazer o que quiser". \\
\hline M8 & "é fazer o que tenho vontade, nunca baixo minha cabeça”. \\
\hline M9 & "é fazer as coisas que eu quero". \\
\hline M10 & "é poder ir para onde quiser”. \\
\hline M11 & "é poder estudar, trabalhar e ir para a igreja”. \\
\hline M12 & "ser dependente da pessoa mesmo". \\
\hline
\end{tabular}

Nesse contexto, é notável que estas mulheres entendam que o empoderamento a princípio deve ocorrer de forma interna, e posteriormente este se deve percorrer para o âmbito externo e que deve atingir não apenas o contexto familiar, mas toda ordem social. Nas falas das alunas é possível afirmar que essas entendem por empoderamento o ato de ser livre em suas escolhas, é não serem oprimidas, é possuir a total liberdade, é poder se expressar diante qualquer contexto social, é ter autonomia, enfim é ter seus direitos garantidos politicamente, juridicamente e economicamente, nesse sentido Stromquist (1997) conplementa: 
Libertar-se é querer ir mais adiante, marcar a diferença, realizar a condições que regem a alteridade nas relações de gênero, de modo a afirmar a mulher como um indivíduo autônomo, independente, dotado de plenitude humana é tão sujeito diante do homem, quanto o homem diante da mulher. (STROMQUIST, 1997, p. 101).

O empoderamento é resultado de grandes enfrentamentos pessoais e sociais no qual a mulher perpassa em sua trajetória de vida, almejando a tão sonhada autonomia, liberdade de expressão e o direito de igualdade, visando assim adquirir condições que lhes assegure uma vida financeira digna, sem necessitar de apoio de terceiros para sobreviver, ainda sobre autonomia Stromquist (1997) aponta que a autonomia da ênfase ao conceito de empoderamento, pois, envolve o poder desde dentro para que as mulheres possam exercer qualquer poder sobre os outros segmentos da sociedade. Desta forma, entende-se que reconhecer-se como "sujeito" autônomo é um dos fatores que influencia para que o indivíduo venha tornar-se empoderado, uma vez que para que tais ações aconteçam se faz necessário que o "sujeito" esteja apto a realizar mudanças e enfrentar as mesmas com muito fervor e conhecimento, sem se inibir diante os obstáculos e empecilhos que surgirem em sua trajetória.

Ao questionarmos se o processo de escolarização influencia/ou influenciou no seu empoderamento, obtivemos o total de $100 \%$ afirmando que sim, estas informam que através dos estudos hoje se sentem livres, mencionam que não precisam de ajuda de terceiros para realizarem pequenas ações que necessitem fazer uso da leitura e escrita, se consideram autônomas, cientes de seus direitos, enfim, mulheres empoderadas, determinadas e objetivas para cumprir com suas ações diárias (Quadro 15).

Quadro 15. Respostas das mulheres pesquisadas em relação à pergunta: estudar na modalidade EJA fez com que você sentisse uma mulher empoderada. Queimadas-PB. 2019

\begin{tabular}{|c|c|}
\hline Pesquisadas & Falas \\
\hline M1 & "fez sim, já vou pros cantos e já sei ler um pouquinho e isso me ajuda, sei que um dia vou fazer meu livro". \\
\hline M2 & "sim, porque depois que estudo já consegui viajar para vários lugares que eu queria”. \\
\hline M3 & "ajuda e muito, somos livres para tudo”. \\
\hline M4 & "sim, hoje eu sou livre”. \\
\hline M5 & "ajudou sim, hoje eu vou e venho sem precisar de ajuda”. \\
\hline M6 & "com certeza, muda muito nossa vida”. \\
\hline M7 & "com certeza, hoje sou livre para fazer o que eu quiser”, na escola aprendemos muita coisa”. \\
\hline M8 & "com certeza, ficamos mais aberta para o mundo”. \\
\hline M9 & "ajuda sim, ajuda a gente a aprender e a viver no mundo”. \\
\hline M10 & "sim, com certeza, através dos estudos me sinto mais independente”. \\
\hline M11 & Ajuda sim, hoje eu vejo o quanto a escola pode mudar nossas vidas". \\
\hline M12 &
\end{tabular}

Assim sendo, nota-se que de fato a escolarização através da modalidade EJA pode favorecer para o processo de emancipação das mulheres vindo a resultar em resultados positivos para a vida pessoal e social destas alunas, pois o que estas buscam é o direito de poder agir diante uma sociedade de forma igualitária, no qual possam atuar de maneira colaborativa, partilhada, unida, somando forças, almejando uma democracia sem hierarquia, sem opressão e com muito comprometimento.

Sobre o levantamento quantitativo das mulheres que buscaram o processo de escolarização na EJA, no Município de Queimadas-PB nos últimos 10 anos não foi possível ser realizado. Buscou-se os bancos de dados da Secretaria Municipal de Educação e de acordo com os técnicos e funcionários, esses dados não estão mais armazenados no Sistema e por conta disso não se pode ter acesso. 


\section{CONSIDERAÇÕES FINAIS}

Pode-se afirmar que as alunas que participaram desse estudo, em sua maioria são adultas, com idade superior a 40 anos, em grande maioria são casadas e tem filhos, sobrevivem com a renda de um salário mínimo para realização de todas suas necessidades, poucas trabalham de forma renumerada. Delas o maior vínculo empregatício se dá através da função de diarista e as demais são provedoras do lar.

Detectou que historicamente estas mulheres advêm de uma classe social de baixa renda e que tiveram que abandonar os estudos enquanto crianças ou jovens para trabalhar (de forma renumerada ou não) e assim contribuir para sua sobrevivência e de seus familiares, além desse fator também foi possível observar que muitas evadiram das atividades escolares, pois elas não viam o processo de escolarização como algo primordial para seu desenvolvimento pessoal, nesse sentido tais elementos são fatores importantes que nos ajudaram a entender o motivo pelo qual nenhumas das pesquisadas concluíram o Ensino Fundamental I na época considerada regular.

Em relação à escola em que a pesquisa foi aplicada, verificamos que nesta existem três turmas voltadas para a Educação de Jovens e Adultos, na qual o número de discentes mulheres matriculadas neste estabelecimento de ensino é superior aos do sexo masculino, fazendo-nos perceber que tais informações reafirmam o que os suportes teóricos nos apresentaram, cabendo mencionar que os docentes que atuam nessas salas de aula são do sexo feminino.

Ao tratar dos fatores que lhes motivaram para irem à busca de escolarização constatamos que objetivo maior é o de adquirir maiores conhecimentos para um melhor crescimento pessoal e profissional, assim como elevar o nível de escolaridade, almejando assim um trabalho que ofereça uma renumeração justa por suas atividades, também nos aparece como resultado a busca por reconhecimento e voz ativa perante a sociedade, buscando assim conquistar um espaço social mais elevado.

Ficou claro que estas mulheres tiveram que abandonar os estudos no início da adolescência por falta de oportunidade, assim como pelo contexto no qual estavam inseridas, pois estas eram submissas às subordinações imposta pesa sociedade machista, onde o processo de escolarização para mulheres não era valorizado, fazendo com que nenhuma das alunas participantes da pesquisa concluísse o Ensino Fundamental I na idade regular. Nesse aspecto, o tempo de afastamento da evasão até o regresso escolar (agora já nas turmas de EJA) varia de 20 a 40 anos, sendo este um fator que mais uma vez nos direciona aos estudos teóricos, visto que analisando historicamente a durabilidade do afastamento, faz nos perceber que estas regressam em épocas atuais na qual as conquistas femininas já estão em maior evidência, gerando assim uma maior confiabilidade para continuar os estudos.

Evidenciou-se também que o motivo que lhes fizeram regressar aos estudos está direcionado ao ato fazer bom uso da prática de leitura e escrita, a fim de modificar várias ações em suas vidas, assim como almejar elevar o nível de conhecimento com intuito de se valorizarem pessoalmente, conhecendo seus direitos e lutando para que tais sejam cumpridos e consequentemente alterarem sua qualidade de vida, na qual buscam o elevar nível de escolarização, valorização profissional, respeito, autonomia e liberdade.

Percebemos que metade das pesquisadas tem apoio familiar para regressar a escola e nela permanecer, sendo este um fator que deve ser considerado como uma importante conquista para estas alunas, afinal tal ação 
ajuda a superar o que no passado não existia (apoio e compreensão), no entanto vale ressaltar que nesse aspecto os filhos em sua grande maioria é que se destacam para esse acontecimento, nesse sentido tal apoio pode ser sinônimo para que o regresso seja eficaz e prazeroso, no entanto, infelizmente ainda existe a falta de apoio dentro dos lares, principalmente por parte dos maridos, sendo este mais um obstáculo a ser superado, mais um desafio a ser enfrentado. É nesse aspecto que vejo a necessidade de se investir mais em políticas públicas que visem amenizar esse problema, nesse necessário mobilizar não apenas as mulheres para movimentos, mas sim toda a população em especial os homens para através do diálogo buscar conscientizar e sensibilizar aqueles que ainda não aceitam essas mudanças sociais.

Não podemos negar o quanto é difícil para estas mulheres permanecerem em sala de aula, pois muitos fatores contribuem para que esse processo não se concretize. Isto é notável nas falas das pesquisadas quando afirmam que o processo de escolarização entre as mulheres é bem mais difícil do que para os homens, pois elas reconhecem o quanto é árduo e cansativo atender as múltiplas atribuições que trazem consigo (filha, mãe, esposa, donas do lar, funcionária) fazendo-nos perceber que mesmo o ensino sendo oferecido a todos (homens e mulheres) "cumprindo" assim com o direito de igualdade, agora necessitamos lutar pelo direito de equidade, afinal ainda esta muito longe de afirmamos que conquistamos a tão sonhada igualdade de gênero, mas para a realização desse desejo é necessário que novas leis sejam criadas com intuito de amenizar essas disparidades, vejo a redução de carga horária de trabalho para as mulheres (sem prejuízo no campo salarial) como uma forma de minimizar essa desigualdade.

Diante de tantas dificuldades apresentadas em relação à busca pela educação escolar (tripla jornada de trabalho, desapego maternal, enfrentamento de preconceito e machismo, superar o cansaço físico e mental, dificuldade para se locomover até a escola, dentre outros) seria interessante que o universo com atende esse alunado buscasse meios que motivassem a permanência dessas alunas em sala de aula, a exemplo de solicitar transporte público para conduzir o alunado, promover palestras que envolvam não apenas as/os alunas/os, mas sim toda a comunidade na qual a escola esta inserida, a fim de apresentar temas que envolvam as práticas de cidadania, direito e igualdade, criar situações em seu plano anual que envolva o contexto família em parceria com a escola, com intuito de mostrar para as famílias destas alunas a importância do processo de escolarização e da necessidade da contribuição de todos.

Apesar de tantas opressões vivenciadas por estas mulheres, encontramos nessas alunas de EJA o gosto pela escola, o prazer em estar inserido em um ambiente alfabetizador, a satisfação de superar a cada dia os obstáculos que vão surgindo, o anseio em expor que as dificuldades estão sendo superadas e que suas vidas estão sendo transformadas e a grande vontade de contagiar as demais mulheres que ainda não conseguiram superar o estado de submissão, pois em seus depoimentos é notável o fervor que as movem, que elas não querem apenas se libertar das prisões impostas, mas que querem ver todas as mulheres caminhando no mesmo sentido, juntas em busca de autonomia. E na buscar por tais conquistas elas nos afirmam que mesmo sofrendo opressões por parte da sociedade, elas encontram na escola, professora, alguns familiares e amigos palavras motivadores que lhes fazem perceber que aos poucos estão se aproximando dos objetivos almejados. 


\section{REFERÊNCIAS}

ANDRADE, S. S. Juventude, processos de escolarização e maternidade. Anais do Fazendo Gênero 8. Florianópolis, ago. 2008.

BEZERRA, S. A. Mulher e mercado de trabalho: a trajetória das mulheres que ocupam cargos de destaque na sociedade sergipana. 2010. Dissertação (Mestrado em Ciências da Educação) - Universidade Lusófona de Humanidades e Tecnologias, Lisboa, 2010.

BORGES, N. A evolução recente da mulher no mercado do trabalho brasileiro: Perspectiva social e econômica. Instituto de Economia, Universidade Estadual de Campinas, Campinas, SP, Brasil, 2009.

BOURDIEU, P. O poder simbólico. São Paulo: Difusão Editorial. 1989.

BRASIL. Instituto Brasileiro de Geografia e Estatística. Conselho Nacional de Estatística. Contribuições par o estudo da demografia no Brasil. Rio de Janeiro: IBGE, 1961. Parte G - Alfabetização, p. 387-448.

BRASIL. Parecer CEB 11/2000: Diretrizes Curriculares Nacionais para a Educação de Jovens e Adultos. Publicada no Diário Oficial da União de 19/07/2000, Seção 1, p. 18.

BRUSCHINI, M. C. A. Trabalho e gênero no Brasil nos últimos dez anos. Cadernos de Pesquisa, São Paulo, v. 37, n. 132, Sept./Dec. 2007.

CARVALHO, M. P. Um olhar de gênero sobre as políticas educacionais. In: gênero e educação. FARIA, Nalu; NOBRE, Miria, et all (orgs). São Paulo: Coleção Cadernos Sempre Viva, 1999.

CASTELLS, M. O poder da identidade. A era da informação: Economia, sociedade e cultura, São Paulo: Paz e Terra, 1999.

COUTINHO, S. Rainhas do crime: ótica feminina no romance policial. Sette Letras, 1994.

DENZIN, N. K.; LINCOLN, Y. S. (Orgs.) O Planejamento da Pesquisa Qualitativa: teorias e abordagens. 2. ed. Porto Alegre, Artmed Bookman, 2006.

FLICK, U. Introdução à pesquisa qualitativa. 2. ed. São Paulo: ARTMED, 2002.

FLICK, U.; NETZ, S.; SILVEIRA, T. Uma introdução à pesquisa qualitativa. Porto Alegre: Bookman, 2. ed. 2004.

GARCIA, R. L. Método; métodos; contramétodo. São Paulo, 2003.

HADDAD, S.; DI PIERRO, M. C. Aprendizagem de jovens e adultos: avaliação da década de Educação para Todos. São Paulo: SEADE, São Paulo em Perspectiva, v. 14, n. 1, p. 29-40, jan-mar., 2000.

HENRY. A. G. Alfabetização e pedagogia do empoderamento político. Teoria da Educação, p. 61-75, 1988,

HERRENKOHL, R. C.; JUDSON, G. T.; HEFFNER, J. A. Defining and mcasuring employee empowerment. The jounal of Applied Behavioral Science, p. 379-389, 1999.

LEFÈVRE, F.; LEFEVRE, A. M. C. Depoimentos e discursos: uma proposta de análise em pesquisa social. In: Depoimentos e discursos: uma proposta de análise em pesquisa social. 2005.

LÉON, M. (org). Poder y empoderamiento de las mujeres. Santafé de Bogotá: Tercer Mundo y UM Facultad de Ciencias Humanas, 1997. Disponível em: <https://issuu.com.renejaimez/docs/el-empoeramiento-de-las-mujeres $\geq$. Acesso em: 13 set. 2019.

LISBOA, T. K. O empoderamento como estratégias de inclusão das mulheres nas políticas sociais. Anais do seminário Internacional Fazendo Gênero: Corpo, Violência e Poder. Florianópolis, SC, Brasil, 2008.

LOURO, G. L. Gênero sexualidade e educação: uma perspectiva pós-estruturalista. 6. ed. Petropolis: Vozes, 1997.

LOPES. C. Currículos em EJA: saberes e práticas de educadores. Rio de Janeiro: SESC, Departamento Nacional, 2011. 258 p. 
LÜDKE, M.; ANDRÉ, M. E. D. A. Pesquisa em educação: abordagens qualitativas. São Paulo: EPU, 1986.

MARTINS, J.; BICUDO, M. A. V. A. Pesquisa Qualitativa em psicologia: fundamentos e recursos básicos. São Paulo: EDUC/Moraes, 1989.

MELO, M. O. L. Mulheres de sucesso em setores predominantemente masculinos de Belo Horizonte: além do teto de vidro na carreira gerencial. Belo Horizonte, (relatório de pesquisa), 2011.

MINAYO, M. C. S. O desafio do conhecimento. pesquisa qualitativa em saúde, v. 9, 2014.

NOGUEIRA, T.V.L. Educação de Jovens e Adultos e Gênero: um diálogo imprescindível de política educacional destinada às mulheres das camadas populares: In: SOARES, Leoncio. Aprendendo com a diferença. Estudos e pesquisas em Educação de Jovens e Adultos. 2. ed. Belo Horizonte: Autêntica, 2006.

OLIVEIRA, K. V. Aprendizagens em espaços não formais e o empoderamento feminino: um estudo de caso em uma associação da Região Amazônica. 2017. 121 f. Dissertação (Mestrado em Ensino) - Universidade Vale do Taquari, Lajeado, 2017.

PERROT, M. Minha história das mulheres. Trad. CORRÊA, Ângela M. S. São Paulo: Contexto, 2007.

PIOVESAN, F. Direitos humanos, civis e políticos: a conquista da cidadania feminina. In: L. L. BARSTED; PITANGUY, J. o Progresso das mulheres no Brasil 2003-2010. Rio de Janeiro/ Brasília: Cepia/ONU. 2011.

POGGIO, I. S. N. A construção das relações de gênero: implicações dos discursos e das práticas educativas nas formações identitárias dos "sujeitos" da Educação de Jovens e Adultos. In: FAFFIN, M. H. L. F. Educação de jovens e adultos: diversidade e o mundo de trabalho. Ijuí: Unijuí, p. 87-102, 2012.

ROCHA-COUTINHO, M. L. Tecendo por trás dos panos: A mulher brasileira nas relações familiares. Rio de Janeiro: Rocco, 1994.

ROSEMBERG, F. "Educação formal mulher e gênero no Brasil”. Revistas Estudos Feministas, v. 9, n. 2, p. 515$539,2001$.

SAMPIERI, R. H.; COLLADO, C. F.; LUCIO, P. B. O processo de pesquisa e os enfoques quantitativo e qualitativo: rumo a um modelo integral. Metodologia de pesquisa. 3. ed. São Paulo, p. 1-21, 2006.

SCOTT, J. Gênero: uma categoria útil para análise histórica. Educação e Realidade, v. 16, n. 2, 1995.

SOARES, J. L. Aprendendo com a diferença- estudos e pesquisas em educação de jovens e adultos. 2. ed. Belo Horizonte: Autêntica, 2006.144 p.

STROMQUIST, N. La busqueda del empoderamento: em qué puede contribuir el campo de la educaciòn. In: LÉON, M. (org). Poder y empoderamiento de las mujeres. Santafé de Bogotá: Tercer Mundo y UM Facultad de Ciencias Humanas, 1997. Disponível em: <https://issuu.com.renejaimez/docs/el-empoeramiento-de-las-mujeres >. Acesso em: 14 set. 2019.

TRIVIÑOS, A. N. S. Introdução à pesquisa em ciências sociais: a pesquisa qualitativa em educação. São Paulo: Atlas, 1987.

VIEIRA, M. M. F.; ZOUAIN, D. M. Pesquisa qualitativa em Administração. Rio de Janeiro: Editora FGV, 2004.

UNESCO. Declaração de Hamburgo. Agenda para o futuro. V Conferência Internacional de Educação de Adultos. V CONFITEA. Hamburgo, Alemanha. 1997. 